\title{
ANALISIS EKONOMI DAN PERANCANGAN ALAT PENGUPAS KULIT ARI KACANG HIJAU DENGAN METODE VDI 2221
}

(Studi Kasus di UMKM Bakpia 803 Bu Marno, Minomartani, Sleman, DIY)

\author{
Wisnu Pradana J., Dyah Rachmawati L., dan Sutrisno \\ Program studi Teknik Industri Fakultas Teknik Industri \\ Universitas Pembangunan Nasional "Veteran" Yogyakarta
}

\begin{abstract}
Abstrak
Bakpia merupakan makanan khas yang berassal dari Yogyakarta, yang terbuat dari bahan baku kacang hijau. Salah satu tempat yang memproduksi bakpia secara sederhana dan konvensional aadalah di Sentra Bakpia Minomartani, Desa Minomartani, Kecamatan Ngaglik, Kabupaten Sleman, DIY. Makanan yang berasal dari campuran kacang hijau dengan gula, yang dibungkus dengan tepung sebagai kulit luar lalu kemudian dipanggang. Pada proses pembuatannya, bahan baku yang digunakan addalah kacang hijau yang sudah dikupas atau kacang hijau plecetan. Berbeda dengan kacang hijau yang utuh, kacang hijau plecetan memiliki harga yang jauh lebih tinggi dibandingkan dengan kacang hijau yang masih utuh. Oleh karena itu, untuk mengatasi masalah tersebut diperlukan perancangan alat untuk mengupas kulit ari kacang hijau yang efektif dan efisien sehingga dapat menekan harga pokok produksi. Alat pengups kulit ari kacang hijau yang dirancang dalam penelitian ini berupa mesin pengupas. Untuk memulai penelitian ini dilakukan tahap perancangan berdasarkan metode Verein Deutscher Ingenieure (VDI) 2221. Atribut yang digunakan dalam penelitian ini didapatkan dan dijadikan sebagai dasar pengembangan diperoleh dari keinginan konsumen yang kemudian diturunkan menjadi fungsi-fungsi yang harus terpenhui oleh alat yang akan dirancang. Hasil dari perancangan harus diwujudkan dalam bentuk produk nyata dan dilakukan uji coba terhadap alat rancangan tersebut serta melaukan evaluasi yang dilakukan oleh konsumen dan tenaga ahli. Faktor yang yang dipakai dalam uji coba alat ini adalah faktor kelelahan, faktor kepuasan pelanggan yag terdiri dari kenyamanan alat, kemudahan operasi serta keseragaman kualitas pengelupasan. Hasil penelitian ini menunjukan bahwa mesin yang dirancang dalam penelitian ini memppunyai tingkat kelelahan yang rendah yaitu 8,79\% CVL, mendapatkan tingkat biaya pokok pengoperasian alat pengupas sebesar Rp 429,73/ jam atau biaya pokok selama satu hari sebesar Rp 3437,90. Dan tingkat pengembalian investasi alat selama 51 minggu.
\end{abstract}

Kata kunci : mesin pengupas kulit ari, kacang hijau, VDI 221, analisis ekonomi

\section{PENDAHULUAN}

\subsection{Latar Belakang Masalah}

UMKM Bakpia 803 Bu Marno adalah salah satu UMKM di wilayah Minomartani, Kabupaten Sleman khususnya di Sentra Bakpia Minomartani. UMKM ini bergerak dalam bidang kuliner yaitu memproduksi bakpia yang merupakan kuliner khas Yogyakarta. UMKM ini berdiri sejak tahun 2000. UMKM Bakpia $803 \mathrm{Bu}$ Marno memproduksi berbagai macam varian rasa, untuk bakpia yang berjenis basah yaitu kacang hijau, lalu untuk bakpia yang berjenis kering yaitu coklat, keju, green tea dan kumbu hitam.

UMKM Bakpia 803 Bu Marno menggunakan bahan baku utama yaitu kacang hijau. Ketika pesanan banyak, UMKM Bakpia $803 \mathrm{Bu}$ Marno ini menggunakan bahan baku kacang hijau yang sudah dikupas kulit arinya (plecetan), bahan baku kacang hijau yang sudah dikupas tersebut mempunyai harga yang tinggi yaitu $\mathrm{Rp} \quad 27.000 / \mathrm{kg}$ dibandingkan kacang hijau yang masih dengan kulitnya yaitu dengan harga

Rp 14.000/Kg. Selain harganya yang mahal, penggunaan bahan baku 
utama kacang hijau plecetan ini tidak dapat disimpan terlalu lama dikarenakan kacang hijau yang sudah terkelupas kulit ari nya lebih cepat terserang hama seperti kutu beras.

Berdasarkan permasalahan tersebut, maka diperlukan alat untuk mengupas kulit ari kacang hijau untuk menekan harga produksi pembuatan bakpia. Penggunaan alat pengupas kulit ari kacang hijau diharapkan dapat mengurangi harga produksi karena tidak perlu lagi menggunakan bahan baku kacang hijau plecetan atau yang sudah dikupas kulit arinya. Perancangan dilakukan dengan metode VDI 2221. Keunggulan menggunakan metode VDI 2221 dilihat dari aspek tujuan metode yaitu dapat membantu para perancang pemula untuk membantu dalam proses perancangan sebuah mesin. Keunggulan lain dari metode VDI 2221 ini adalah pada proses perancangannya dapat menyesuaikan dengan kemampuan konsumen dari segi ekonomi. Selain mengkaji aspek teknik perancangan alat menggunakan metode VDI 2221, penelitian ini juga mengkaji aspek ekonomi dari perancangan alat yang dibuat, yaitu membandingkan biaya produksi ketika menggunakan alat dan ketika tidak menggunakan alat.

\subsection{Perumusan Masalah}

Berdasarkan latar belakang masalah tersebut, maka dapat dirumuskan permasalahan yaitu bagaimana perancangan alat pengupas kulit ari kacang hijau yang sesuai dengan kebutuhan UMKM Bakpia 803 $\mathrm{Bu}$ Marno dan mengetahui analisis ekonomi biaya pengoperasian alatnya?

\subsection{Tujuan Penelitian}

Tujuan dari penelitian ini adalah merancang alat pengupas kulit ari kacang hijau yang sesuai dengan kebutuhan UMKM Bakpia $803 \mathrm{Bu}$ Marno dan mengetahui analisis ekonomi dalam biaya pengoperasian alat

\subsection{Batasan Masalah} adalah

Batasan masalah dalam penelitian ini

1. Penelitian dilakukan di UMKM Bakpia 80 $\mathrm{Bu}$ Marno, Minomartani, Kabupaten Sleman

2. Dalam penelitian ini, tidak dibahas mengenai jenis-jenis dari kacang hijau yang digunakan sebagai bahan penelitian

\subsection{Asumsi Penelitian}

Asumsi yang digunakan dalam penelitian ini adalah:

1. Harga dari kacang hijau dianggap selalu sama atau stabil

2. Alat pengupas kulit ari kacang hijau yang digunakan selama penelitian dianggap berjalan dengan baik

3. Tingkat umur ekonomis alat adalah 5 tahun.

\subsection{Manfaat Penelitian}

Manfaat dari penelitian ini adalah alat pengupas kulit ari kacang hijau yang dihasilkan akan mengurangi biaya produksi UMKM Bakpia 803 dalam memproduksi bakpia

\section{LANDASAN TEORI}

\subsection{Verein Deutscher Ingenieure (VDI)}

Verein Deutscer Ingenieure (VDI) atau Asosiasi Insinyur Jerman, telah menghasilkan beberapa pedoman, termasuk pedoman VDI 2221 yang berisi tentang sistematika pendekatan ke desain teknis sistem dan produk. Pedoman ini menjukkan sistem pendekatan sistematis dimana proses desain sebagai bagian penciptaan produk yang dibagi menjadi tahap kerja secara umum, membuat pendekatan desain transparan, rasional, dan independen dari cabang tertentu industri (Cross, 1994).

\subsection{Langkah kerja VDI}

Secara keseluruhan langkah kerja yang terdapat dalam VDI 2221 terdiri dari 7 tahap, yang dikelompokkan menjadi 4 fase, sebagai berikut (Sutejo, 2012):

1. Penjabaran tugas

Tahap ini meliputi pengumpulan informasi atau data tentang syarat-syarat yang harus dipenuhi oleh rancangan alat tersebut beserta batasan-batasannya. Hasil dari tahap ini berupa syarat-syarat atau spesifikasi.

2. Perancangan konsep produk

Tahapan ini berisi pembahasan tentang permasalahan abstraksi, membuat struktur fungsi, kemudian melakukan pencarian prinsip pemecahan masalah yang cocok dan kombinasi dari prinsip pemecahan masalah 
tersebut (konsep varian). Hasil dari tahap ini berupa pemecahan dasar atau konsep.

3. Perancangan wujud produk

Sketsa kombinasi prinsip solusi yang telah dibuat merupakan bentuk layout awal, kemudian dipilih yang memenuhi persyaratan yang sesuai dengan spesifikasi dan baik menurut kriteria, baik dari aspek teknis maupun ekonomi. Layout awal yang dipilih akan dikembangkan menjadi layout definitive yang merupakan wujud perancangan yang sesuai dengan kebutuhan dan harapan.

4. Perancangan rinci

Tahapan ini merupakan tahap akhir dalam perancangan. Hasil perancangan detail berupa dokumen yang meliputi gambar mesin, detail gambar mesin, daftar komponen, spesifikasi bahan, sistem pengoperasian, toleransi dan dokumen lainnya yang merupakan satu kesatuan. Kemudian dilakukan evaluasi kembali terhadap produk, apakah benar-benar sudah memenuhi spesifikasi yang diberikan

\subsection{Analisis Ekonomi}

Menurut Hunt (1986) Analisis ekonomi adalah proses dimana kekuatan dan kelemahan suatu ekonomi dianalisis. analisis ekonomi adalah penting untuk memahami kondisi ekonomi yang tepat. Hal ini dapat mencakup sejumlah isu-isu ekonomi penting yang terus cropping up dalam ekonomi tertentu, yang sedang dianalisis.

\subsection{Biaya Tetap}

Biaya tetap merupakan biaya yang tidak berubah terhadap perubahan output. Biaya tetap adalah biaya-biaya yang konstan secara total dalam relevant range terhadap variasi level dari activity driver (Hansen and Mowen, 2009).

Biaya tetap total jumlahnya sama sepanjang proses produksi. Artinya walaupun produk yang diperoleh banyak atau sedikit jumlahnya akan tetap. Namun biaya tetap ratarata tergantung pada besar kecilnya produksi.

\subsection{Biaya Tidak Tetap (Variable Cost)}

Menurut Mulyadi (2005) Biaya tidak tetap yaitu kebalikan dari biaya tetap, biaya variabel ini bersifat dinamis. Ia mengikuti banyaknya jmulah unit yang diproduksi ataupun banyaknya aktivitas yang dilakukan. Pada biaya ini, jumlah yang akan kita keluarkan per unit atau per aktivitas justru berjulah tetap sedangkan untuk biaya secara total jumlahnya akan menyesuaikan dengan banyaknya jumlah unit yang diproduksi ataupun jumlah aktivitas yang dilakukan. Jika biaya tetap memiliki hubungan terbalik dengan jumlah unit yang diproduksi atau aktivitas yang dilakukan maka, secara total biaya variabel memiliki hubungan searah dengan jumlah unit yang diproduksi atau aktivitas yang

dilakukan.

\section{KERANGKA PENELITIAN}

Gambar kerangka penelitian dapat di lihat pada Gambar 1. 


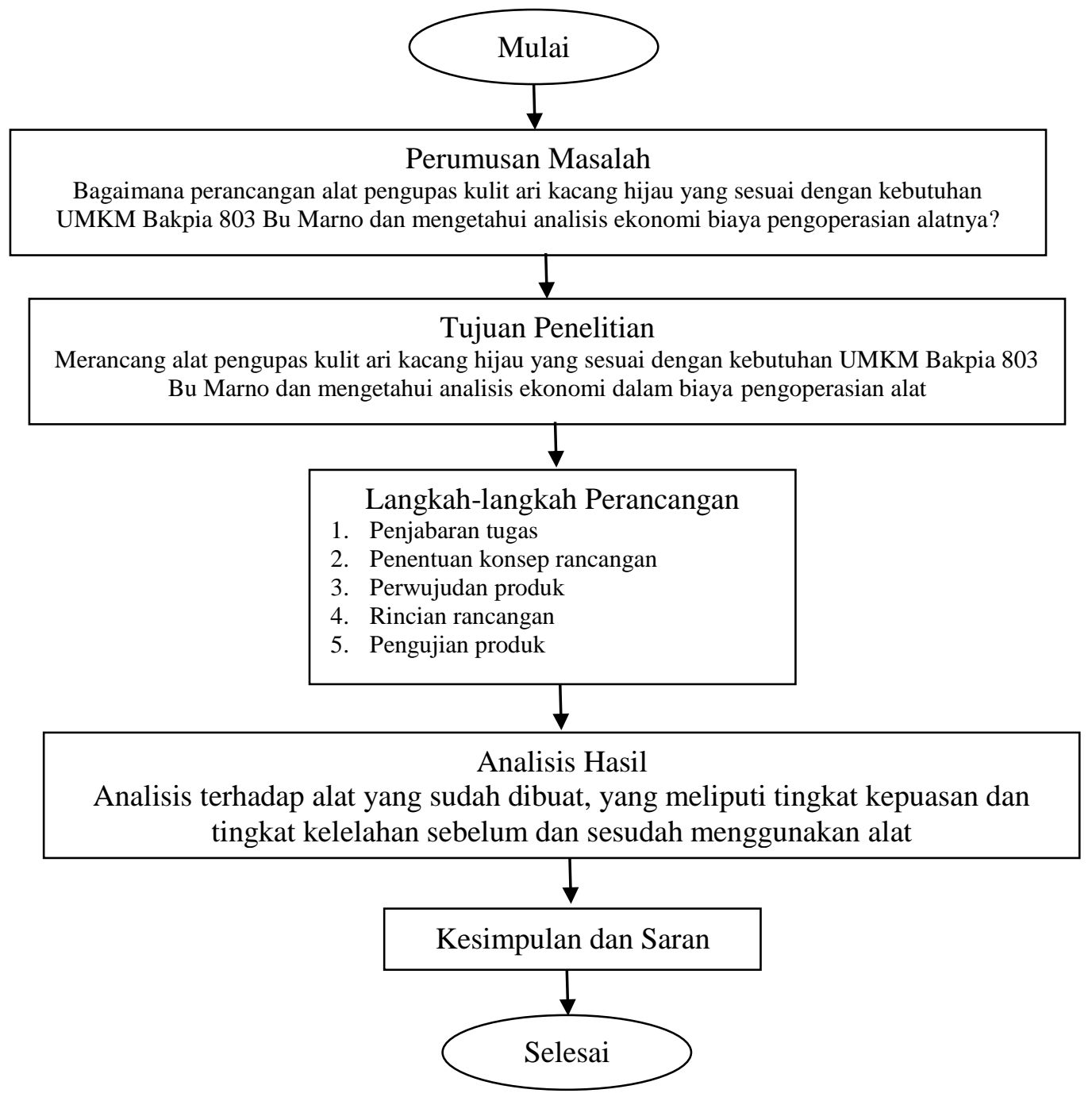

Gambar 1. Kerangka penelitian

\section{PERANCANGAN PRODUK DAN ANALISIS HASIL}

\subsection{Penjabaran Tugas}

4.1.1 Wawancara pra penelitian

Pada tahap pertama untuk pengumpulan data dalam penelitian in adalah dengan melalakukan wawancara kepada pemilik di UKM Bakpia yang khususnya berada di Sentra Bakpia Minomartani, Sleman, Yogyakarta yang berisi mengenai informasi tentang kondisi yang dialami oleh UKM, informasi mengenai permasalahan yang dihadapi oleh pemilik di UKM Bakpia Sentra bakpia Minomartani serta informasi tentang kriteria terhadap rancangan mesin pengupas kulit ari kacang hijau.

\subsubsection{Kuisioner}

Tahap kuisioner ini disebarkan pada bulan juli tahun 2018 yang ditujukan kepada pemilik dan pekerja pada UKM Bakpia di Sentra Bakpia Minomartani, Sleman, Yogyakarta. Kuisioner ini dibuat bertujuan untuk mengetahui keadaan dari proses produksi dan spesifikasi mesin keinginan pekerja terhadap pertimbangan alart baru.

\subsection{Perancangan Konsep Produk}

4.2.1 Penyusunan Konsep Rancangan 
Langkah penyusunan konsep rancangan pada pengembangan produk perlu dilakukan secara terstruktur untuk mengantisipasi kesalahan saat melakukan perancangan produk. Penyusunan konsep rancangan mesin pengupas kulit ari kacang hijau ini berdasarkan dari informasi kebutuhan konsumen dan usulan perbaikan yang diperoleh dari pengelompokan hasil jawaban kuisioner perancangan mesin pengupas kulit ari kacang hijau.

4.2.2 Identifikasi Masalah serta Penentuan Fungsi dan Struktur

Tahap awal dalam penentukan konsep rancangan yaitu dengan menggambarkan dengan cara penggamabaran model "Black Box" terhadap mesin pengupas kulit ari kacang Hijau. Model "Black Box" ini bertujuan ini menentukan fungsi penyusun sisten dalam hubungan transformasi antara input, fungsi dan output. Kemudian dilanjutkan dengan tahapan penentuan sub-sub fungsi dalam blol diagram berbentuk model "Transparent Box".

\subsubsection{Mencari Prinsip Solusi}

Tahap ini menghasilkan alternatif berdasarkan dari hasil wawancara dan penyebaran kuisioner kepada teknisi, pemilik dan pekerja UMKM. Alternatif dari setiap komponen memiliki kriteria-kriteria untuk perancangan mesin pengupas kulit ari kacang hijau. Alternatif yang terpilih kemudian akan menjadi bahan dalam pembuatan mesin pengupas kulit ari kacang hijau.

\section{Rangka}

Dari hasil wawancara didapatkan alternatif pada komponen rangka adalah Alumunium. Alumunium sendiri dapat dengan mudah dibentuk sesuai dengan kebutuhan, ringan, tahan karat. Alternatif kedua dari komponen rangka adalah galvalum, galvalum mempunyai kekuatan yang tinggi, mempunyai harga yang murah dan memiliki tingkar umur yang panjang.

2. Corong masuk

Berdasarkan hasil wawancara didapatkan alternatif bahan untuk komponen corong masuk adalah alumunium dan plastik. Alternatif dari bahan alumunium mempunyai umur bahan yang panjang, dan memiliki kekuatan yang tinggi. Alternatif kedua adalah plastik, plastik mempunyai harga yang lebih ekonomis dan sangat mudah dibersihkan.

3. Motor penggerak

Berdasarkan hasil wawancara didapatkan alternatif bahan untuk komponen motor penggerak adalah motor penggerak dengan daya $1 / 2$ HP dan motor penggerak dengan daya $1 / 4 \mathrm{HP}$. Alternatif bahan dengan motor penggerak daya $1 / 2$ HP memiliki kecepaatan putar yang tinggi dan mampu memutar beban yang lebih berat. Alternatif bahan kedua adalah motor penggerak 1/4 HP, motor penggerak $1 / 4$ HP memiliki daya konsmusi listrik yang irit, harga nya yang terjangkau dan teknis perawatan yang relatif lebih mudah.

4. Wadah Penyaring

Berdasarkan hasil wawancara didapatkan alternatif bahan untuk komponen wadah penyaring adalah alternatif bahan stainless steel dan alumunium. Alternatif bahan staineless steel memiliki daya tahan terhadap air yang sangat tinggi, mudah dibentuk dan ringan. Alternatif bahan alumunium memiliki harga yang terjangkau, tahan karat dan memiliki tingkat umur bahan yang panjang.

5. Disk pengelupas

Berdasarkan hasil wawancara didapatkan alternatif bahan untuk komponen disk pengelupas yaitu alternatif bahan cor semen dan alternatif bahan batu. Alternatif bahan cor semen memiliki beban yang ringan, dan tingkat umur bahan yang panjang. Alternatif bahan batu untuk komponen disk pengelupas memiliki harga yang terjangkau, kekuatan yang kuat dan teknis membersihkan yang sangat mudah.

6. Sistem penggerak motor mesin

Berdasarkan hasil wawancara didapatkan alternatif bahan untuk komponen penggerak motor mesin yaitu v-belt dan pulley serta gear dan rantai. Alternatif bahan v-belt dan pulley memiliki harga yang terjangkau, teknis perawatan yang mudah serta mudah diganti apabila mengalami kerusakan. Alternatif bahan gear dan rantai memiliki tingkat kekuatan 
yang tinggi, tingkat umur bahan yang panjang dan tahan lama.

Pemilihan alternatif bahan komponen mesin pengupas kulit ari kacang hijau berdasarkan hasil kuisioner berdasarkan bobot tertinggi didapatkan, rangka yang digunakan terbuat dari galvalum, corong masuk menggukan alumunium, motor penggerak menggunakan motor $1 / 4 \mathrm{HP}$, wadah penyaring menggunakan stainless steel, disk pengelupas menggunakan batu dan sistem penggerak motor menggunakan $V$-belt dan Pulley

4.2.4 Menentukan Tinggi Mesin

Menggunakan Antropometri

Mesin pengupas kulit ari kacang hijau ini dioperasikan dengan posisi berdiri sehinggi tinggi corong masuk dapat mempengaruhi dari kinerja pekerja saat menggunakan alat tersebut. Tinggi mesin pengupas kulit ari ditentukan dari tinggi siku orang berdiri. Data yang digunakan untuk penentuan tinggi mesin pengupas kulit ari menggunakan data anthropometri masyarakat indonesia dengan menggunakan persentil $50 \%$ yaitu dimaksudkan untuk tinggi rata-rata masyakarat Indonesia. Berdasarkan tinggi siku orang berdiri maka dapat disimpulkan bahwa tinggi mesin pengupas kulit ari kacang hijau adalah $98,05 \mathrm{~cm} \approx 98 \mathrm{~cm}$.

\subsection{Perancangan Wujud}

Setelah proses penguraian konsep rancangan produk mesin pengupas kulit ari kacang hijau proses perancangan pada tahap ini dilakukan dengan mewujudkan konsep rancangan menjadi wujud nyata dengan membuat gambar rancangan 3D yang ditunjukkan pada Gambar 2.

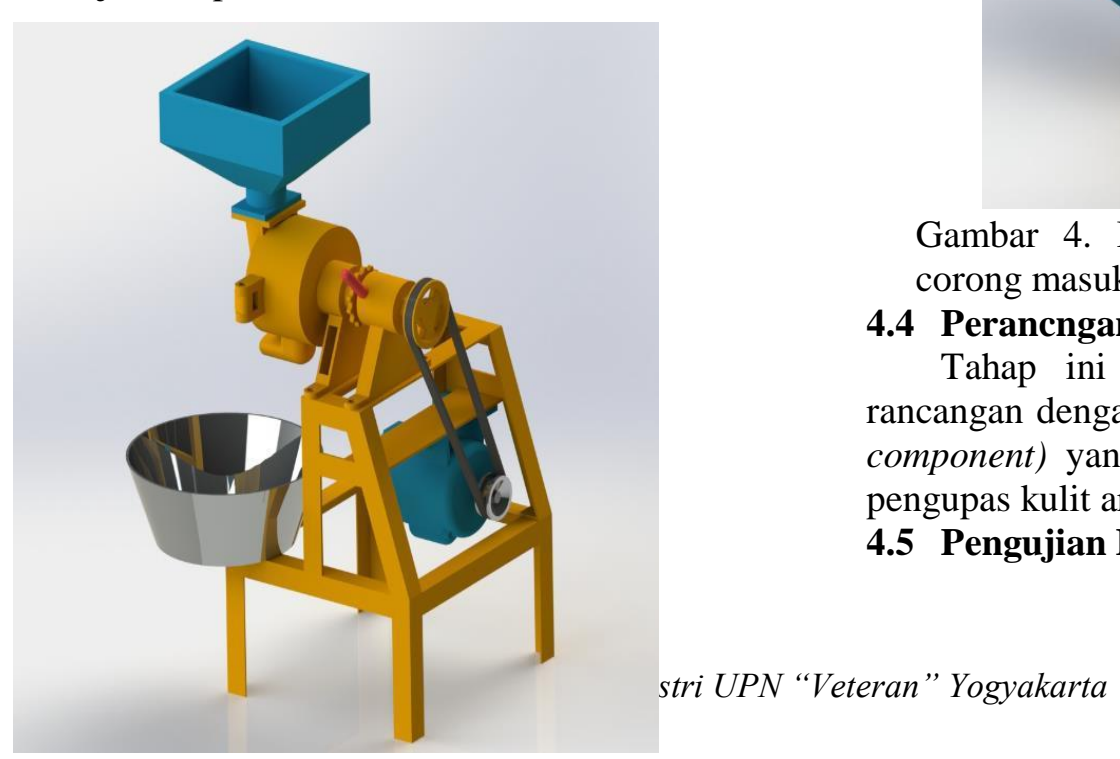

\section{Rangka kaki} pada Gambar 4.

Gambar 2. Rancangan mesin pengupas kulit ari kacang hijau

Komponen utama mesin pengupas kulit ari kacang hijau terdiri atas :

Komponen ini berfungsi sebagai penopang dan pondasi sistem penggerak sekaligus penguhubung dari rangka dengan disk pengelupas dan corong masuk. Bentuk rangka dapat dilihat pada Gambar 3.

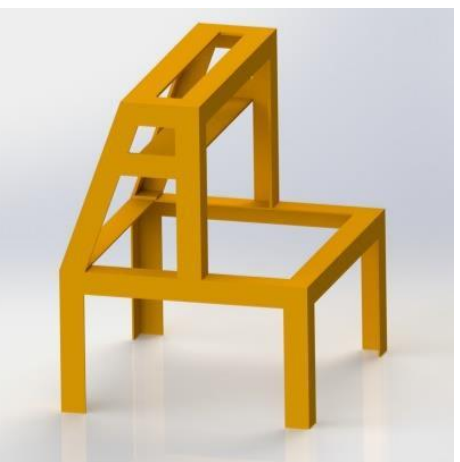

Gambar 3. Rangka kaki mesin pengupas kulit ari kacang hijau

2. Bagian disk pengelupas dan corong masuk Komponen ini berfungsi sebagai penghubung antara penopang/rangka dengan komponen disk pengelupas dan corong msauk. Bentuk gambar dapat dilihat

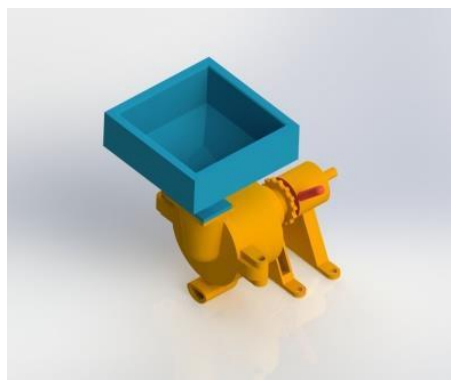

Gambar 4. Bagian disk pengelupas dan Perancngan Rinci kacang hijau. 


\subsubsection{Uji Kelelahan Pekerja}

Berdasarkan hasil uji kelelahan pada satu kali proses pengupasan yang dilakukan pada 1 pemilik dan 2 pekerja memiliki rata-rata $\% H R$ Reserve dan \%CVL sebesar 6,72. Sedangkan untuk hasil uji kelelahan untuk lima kali proses per satu kali ukur didapatkan hasil ratarata \%HR Reserve dan \%CVL sebesar 11,32. Hasil yang didapatkan berdasarkan uji keleahan ini menunjukan \%HR Reserve dan $\%$ CVL dari pada pekerja rata-rata yang rendah dimana dalam klasifikasi \%CVL hasil nya dibawah $30 \%$ yang menunjukan tidak terjadinya kelelahan

4.5.2 Tingkat Kepuasan

Tingkat kepuasan diujikan untuk mengetahui fungsi dari mesin hasil pengembangan sudah sesuai dengan keinginan dari pengguna atau belum. Uji tingkat kepuasan ini dilakukan dengan melakukan penyebaran kuisioner kepada pekerja UKM Bakpia dan pemilik UKM Bakpia $803 \mathrm{Bu}$ Marno. Hasil dari kuisioner dihitung dengan meggunakan skala likert. Setalah menghitung skala likert pada setiap responden hasil dari tingkat kepuasan dapat dilihat pada Tabel 1 .

Tabel 1. Hasil Uji Tingkat Kepuasan

\begin{tabular}{|c|c|c|}
\hline $\begin{array}{c}\text { Jenis } \\
\text { Pertanyaan }\end{array}$ & $\begin{array}{c}\text { Skala } \\
\text { Likert }\end{array}$ & Keterangan \\
\hline $\begin{array}{c}\text { Kenyamanan } \\
\text { Alat }\end{array}$ & 4,67 & $\begin{array}{c}\text { Hasil 4,67 berarti } \\
\text { sebagian besar } \\
\text { responden } \\
\text { merasa nyaman saat } \\
\text { menggunakan mesin } \\
\text { pengupas kulit ari } \\
\text { kacang hijau }\end{array}$ \\
\hline $\begin{array}{c}\text { Kemudahan } \\
\text { Pengoperasia } \\
\text { n }\end{array}$ & 4,33 & $\begin{array}{c}\text { Hasil 4,33 berarti } \\
\text { sebagian besar } \\
\text { responden } \\
\text { merasa mudah saat } \\
\text { menggakan mesin } \\
\text { pengupas } \\
\text { kulit ari kacang hijau }\end{array}$ \\
\hline $\begin{array}{c}\text { Keseragama } \\
\text { n Kualitas } \\
\text { Pengelupasa } \\
\text { n }\end{array}$ & 4,33 & $\begin{array}{c}\text { Hasil 4,33 berarti } \\
\text { sebagian besar } \\
\text { responden } \\
\text { merasa hasil yang } \\
\text { didapat dari mesin } \\
\text { pengelupas sesuai }\end{array}$
\end{tabular}

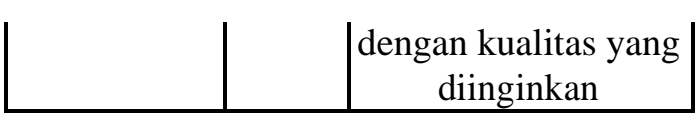

\subsection{Analisa Ekonomi}

Perancangan kulit ari kacang hijau ini juga disertakan dengan analisis ekonomi pengoperasian alat untuk mengetahui apakah dengan menggunakan alat pengupas kulit ari ini dapat lebih ekonomis dibandingkan dengan menggunakan kacang hijau yang sudah terkupas (plecetan) dengan menggunakan kacang hijau utuh yang masih harus menggunakan mesin pengupas. Parameter perhitungan biaya pengoperasian alat dapat dilihat pada tabel berikut.

Tabel 2. Parameter perhitungan biaya pengoperasian alat

\begin{tabular}{|r|l|c|}
\hline No & \multicolumn{1}{|c|}{ Paramater } & Nilai \\
\hline 1. & $\begin{array}{l}\text { Harga alat pengupas } \\
\text { kulit ari kacang hijau } \\
\text { (P), Rp/unit }\end{array}$ & $\begin{array}{c}3,800,0 \\
00\end{array}$ \\
\hline 2. & Umur Alat (N), tahun & 5 \\
\hline 3. & $\begin{array}{l}\text { Harga akhir alat (S) } \\
\text { Rp/unit }\end{array}$ & 380,000 \\
\hline 4. & $\begin{array}{l}\text { Suku bunga bank per } \\
\text { tahun (i) }\end{array}$ & 0,12 \\
\hline 5. & $\begin{array}{l}\text { Biaya tenaga kerja } \\
\text { (L), Rp/hari }\end{array}$ & 70,000 \\
\hline 6. & $\begin{array}{l}\text { Kapasitas } \\
\text { pengadukan (C), } \\
\text { kg/jam }\end{array}$ & 30 \\
\hline 7. & $\begin{array}{l}\text { Jumlah jam kerja per } \\
\text { tahun }\end{array}$ & 1248 \\
\hline
\end{tabular}

Perhitungan biaya pokok pengelupasan kulit ari kacang hijau dapat dilihat pada Tabel 3.

Tabel 3. Perhitungan biaya pokok pengelupasan kulit ari kacang hijau

\begin{tabular}{|r|l|l|}
\hline No & Parameter & Nilai \\
\hline & Biaya Tetap & \\
\hline 1 & $\begin{array}{l}\text { Penyusutan (D), Rp / } \\
\text { th }\end{array}$ & 684,000 \\
\hline 2 & $\begin{array}{l}\text { Investasi dan bunga } \\
\text { modal (I), Rp/th }\end{array}$ & 273,600 \\
\hline 3 & Biaya gudang & 38,000 \\
\hline \multicolumn{2}{|r|}{$\begin{array}{r}\text { Total biaya tetap } \\
\text { (Rp/th) }\end{array}$} & 995,600 \\
\hline
\end{tabular}




\begin{tabular}{|r|l|c|} 
& Biaya Tidak Tetap & \\
\hline 4 & $\begin{array}{l}\text { Biaya pemeliharaan, } \\
\text { Rp/jam }\end{array}$ & 410,4 \\
\hline 5 & $\begin{array}{l}\text { Biaya operator, } \\
\text { Rp/hari }\end{array}$ & 80,000 \\
\hline 6 & Biaya listrik, Rp/hari & 2934 \\
\hline \multicolumn{3}{|c|}{ Total biaya tidak tetap } \\
\hline & $\begin{array}{l}\text { Biaya Pokok } \\
\text { Pengelupasan (Rp/kg) }\end{array}$ & 42,094 \\
\hline
\end{tabular}

Berdasarkan perhitungan biaya pokok pengupasan kulit ari didapatkan biaya pokok sebsear Rp 429,73/ jam atau biaya pokok selama satu hari sebesar Rp 3437,90.

4.6.1 Perhitungan Payback Period

Perhitungan payback period (PP) dihitung untuk mengetahui berapa biaya modal yang ditanamkan dan pengembalian modal dalam membeli sebuah alat pengupas kulit ari kacang hijau.. Pada pengembalian investasi mesin pengupas kulit ari kacang hijau, pihak Bakpia $803 \mathrm{Bu}$ Marno akan menyisihkan Rp 75,000 /minggu. Sehingga untuk perhitungan pengembalian investasi mesin dapat dilihat sebagai berikut dengan persamaan:

$\mathrm{PP}=\mathrm{I} / \mathrm{A}$

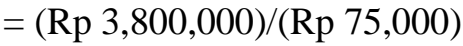

$$
\begin{aligned}
& =50,67 \approx 51 \mathrm{minggu}
\end{aligned}
$$

4.6.2 Perbandingan Harga Pokok Produksi Menggunakan Alat dengan Kacang Hijau Plecetan

4.6.2.1 Harga pokok produksi dengan menggunakan mesin pengupas kulit ari kacang hijau

Komponen penghitungan harga pokok produksi pembuatan bakpia menggunakan alat pengupas kulit ari kacang hijau terdiri dari biaya bahan baku, biaya tenaga kerja langsung, dan biaya overhead pabrik. Harga pokok produksi dan prosentase keuntungan yang didapatkan ketika memproduksi bakpia menggunakan alat pengupas kulit ari kacang hijau dapat dilihat pada tabel berikut.

Tabel 4. Prosentase keuntungan dg alat

\begin{tabular}{|c|c|}
\hline Harga pokok produksi & $\mathrm{Rp} 684.172,-$ \\
\hline Harga jual 1 dus & $\mathrm{Rp} \mathrm{20.000,-}$ \\
\hline Harga 1 dus tanpa untung & $\mathrm{Rp} \mathrm{13.688}$ \\
\hline Prosentase Keutungan & $31 \%$ \\
\hline
\end{tabular}

4.6.2.2 Harga pokok produksi dengan menggunakan kacang hijau plecetan

Harga pokok produksi dan prosentase keuntungan yang didapatkan ketika memproduksi bakpia tanpa menggunakan alat pengupas kulit ari kacang hijau (menggunakan kacang hijau plecetan) dapat dilihat pada tabel berikut.

Tabel 5. Prosentase keuntungan dg plecetan

\begin{tabular}{|l|c|}
\hline $\begin{array}{l}\text { Harga pokok } \\
\text { produksi }\end{array}$ & $\mathrm{Rp} \mathrm{763.634,-}$ \\
\hline Harga jual 1 dus & $\mathrm{Rp} \mathrm{20.000,-}$ \\
\hline $\begin{array}{l}\text { Harga 1 dus tanpa } \\
\text { untung }\end{array}$ & $\mathrm{Rp} \mathrm{15.272}$ \\
\hline $\begin{array}{l}\text { Prosentase } \\
\text { Keutungan }\end{array}$ & $23,64 \%$ \\
\hline
\end{tabular}

Berdasarkan perhitungan diketahui bahwa prosentase keuntungan memproduksi bakpia menggunakan alat lebih besar daripada prosentase keuntungan ketika memproduksi bakpia menggunakan plecetan.

\section{KESIMPULAN}

Berdasarkan penelitian mengenai perancangan mesin pengupas kulit ari kacang hijau pada UMKM Bakpia 803 Bu Marno, maka dapat disimpulkan sebagai berikut: 1) Telah dapat dirancang alat pengupas kulit ari kacang hijau yang sesuai dengan kebutuhan UMKM Bakpia 803 Bu Marno; 2) Prosentase keuntungan memproduksi bakpia menggunakan alat pengupas kulit ari kacang hijau adalah $31 \%$, sedangkan prosentase keuntungan memproduksi bakpia tanpa menggunakan alat pengupas kulit ari kacang hijau adalah 23, $64 \%$.

\section{DAFTAR PUSTAKA}

Cross, N., 1994, Engineering Design Methods: Strategies for Product Design, Second Edition, John Wiley and Sons Ltd., United Kingdom.

Ginting, R., 2010, Perancangan Produk, Cetakan Pertama, Graha Ilmu, Yogyakarta.

Hansen, Don, and Mowen M M. . 2009. Akuntansi Manajemen Edisi Ke 8, Erlangga , Jakarta. 
Hunt, D.R. 1986. Engineering Models for Agiculture Production. The AVI Publishing company, Inc Wesport, Connecticut.

Mulyadi, 2005, Akuntansi Biaya, Edisi Kelima,: Unit Penerbit dan Pecetakan Akademi Manajemen Perusahaan YKPN. Yogyakarta.

Sutejo, Agus, dan Prayoga, A.R.,2012, Rancang Bangun Alat Pengupas Kulit ari Kacang Tanah (arachis hypogae) Tipe Engkol,Jurnal Keteknikan Pertanian.

Sutalaksana, I.Z., Anggawisastra, R., dan Tjakraatmadja, J.H., 1979, Teknik Tata Cara Kerja, Institut Teknologi Bandung, Bandung 